\title{
Immobilization of Lipase-Producing Bacteria Acinetobacter baumannii on Paddy Straw Powder
}

\author{
I Putu Parwata* and Made Vivi Oviantari \\ Department of Analytical Chemistry, Faculty of Mathematics and Natural Sciences, \\ Universitas Pendidikan Ganesha, Jalan Udayana 11, Singaraja 81116, Indonesia. \\ http://dx.doi.org/10.13005/bbra/2082
}

(Received: 11 April 2016; accepted: 04 June 2016)

\begin{abstract}
The use of immobilized bacteria as biocatalyst is more interesting than pure enzyme because of its stability and low production cost. In this study, Acinetobacter baumannii isolated from oil contaminated soil in Pasar Anyar Singaraja Bali was immobilized on paddy straw powder to know the characteristics and stability of the lipase produced. The bacteria were grown in lipase production media with the composition of (w/v): $0.5 \%$ peptone, $0.5 \%$ yeast extract, $0.1 \% \mathrm{NaCl}, 0.05 \% \mathrm{CaCl}_{2}$, and then immobilized on the adsorbent which was activated by $\mathrm{CaCl}_{2}$ solution with various concentrations ( 0 to $45 \%$ w/v). Immobilization was done by using adsorption technique by varying the culture age (8-24 hours). The activity of the lipase produced by the immobilized bacteria was tested and characterized by parameters of $\mathrm{pH}$, temperature, catalysis stability and stability in ethanol and methanol. The results showed optimum immobilization was reached when using straw powder activated with $20 \%$ of $\mathrm{CaCl}_{2}$ solution and at 20 hours of culture age. Immobilized bacteria showed optimum lipase activity at pH 8.5 and temperature of $45{ }^{\circ} \mathrm{C}$ with a value of 0.336 units/g. Immobilized bacteria were able to maintain their activity up to $51 \%$ after seven times of catalytic process. Interestingly, immobilized bacteria showed good stability in methanol, so it is best used as a biocatalyst in the production of biodiesel.
\end{abstract}

Key words: Immobilization, Acinetobacter baumannii, paddy straw powder, lipase.

Lipase (triacylglycerol hydrolase, EC 3.1.1.3) is widely used as a catalyst in food industry, chemicals, detergents, cosmetics, pharmaceutical, sewage and water treatment, textiles, as well as the application of biotechnology ${ }^{1}$. Lipase is able to catalyze the hydrolysis of lipids as well as synthesis reactions such as esterification, transesterification, transformation of chemo-, regio, and stereoselective ${ }^{2}$.

Lipase is produced by microorganisms such as bacteria, mold and fungi. Lipase from microbes is widely used in industry because of its

\footnotetext{
* To whom all correspondence should be addressed. Tel.: +62 362 25072; Fax: +62 36225335

E-mail : iputuparwata@gmail.com
}

stability, selectivity and wide specificity of the substrates $^{3,4}$. To improve its catalytic stability, generally lipase is immobilized on supporting media. But purification of the enzyme to be immobilized is complex and expensive, therefore this technique is less efficient ${ }^{5}$.

Nowadays the production of lipase from immobilized microbial cells is more attractive. With this technique, the cost required for the isolation, purification and immobilization of enzymes can be omitted $^{6,7}$. Immobilization of microbial cells facilitates enzyme production and maintains its catalytic activity for a long time ${ }^{8}$. Immobilization of microbial cells increases biomass production, metabolic activity of cells, and cell resistance to various toxic materials ${ }^{9,10}$. Lip a se-producing bacteria Acinetobacter baumannii isolated from 
oil contaminated soil at Pasar Anyar, a traditional market in Singaraja Town, Bali was immobilized on paddy straw powder. The study aimed to determine the characteristics and stability of immobilized bacteria based on the activity of the lipase produced.

\section{MATERIALSANDMETHODS}

\section{Chemicals}

Chemicals used in this study included yeast extract, peptone, tryptone, $\mathrm{NaCl}, \mathrm{CaCl}_{2}$, bacto agar, $\mathrm{NaHPO}_{4}, \mathrm{Na}_{2} \mathrm{PO}_{4}$, glycine and $\mathrm{NaOH}$ that were purchased from Merck Germany with pro Analysis grade. Acetonitrile, p-nitrofenil palmitate, ethanol and methanol were obtained from Sigma- Aldrich (USA).

\section{Isolation and Identification of Lipase-Producing Bacteria}

Bacteria were isolated from one of the lipolytic potential colonies which had been grown from oil contaminated soil samples taken at the traditional market Singaraja, Bali ${ }^{11}$ (Parwata and Sukarta, 2013). Bacteria were isolated using minimum media Luria Bertani (LB) with the composition of $(\mathrm{w} / \mathrm{v})$ : $0.1 \%$ tryptone, $0.1 \%$ yeast extract and $0.1 \% \mathrm{NaCl}$. The medium was incubated at $37{ }^{\circ} \mathrm{C}$ with shaking at $150 \mathrm{rpm}$ for 20 hours. Inoculum was than diluted in three stages, i.e. $10^{-2}$, $10^{-4}$ and $10^{-6}$ times, then spread on solid LB medium with the composition of (w/v) $0.1 \%$ tryptone, $0.1 \%$ yeast extract, $0.1 \% \mathrm{NaCl}$, and $2 \%$ bacto-agar. The grown colonies were then stroked onto solid LB medium with the same composition using quadrant technique ${ }^{12}$. The latest step was repeated four times to obtain single isolated bacteria. Single isolates were then identified using the system of API (Analytical Profile Index) 20E.

\section{Activation of Paddy Straw Powder}

Paddy straw powder was activated using $\mathrm{CaCl}_{2}$ solution at various concentrations (0-45\% $\mathrm{w} / \mathrm{v})$. The powder soaked in $\mathrm{CaCl}_{2}$ solution with a ratio of $1: 15(\mathrm{v} / \mathrm{v})$, incubated at at $37^{\circ} \mathrm{C}$ with shaking at $150 \mathrm{rpm}$ for 20 hours. The powder was filtered and washed with akuadest to remove residual $\mathrm{CaCl}_{2}$, then dried and sterilized using an autoclave. The surface structure of paddy straw powder was analyzed by SEM (scanning electron microscopy) with 5,000 times of magnification.

Immobilization of Bacterial Cell on Activated

\section{Paddy Straw Powder}

The bacteria were grown in media with the composition (w/v): $0.5 \%$ peptone, $0.5 \%$ yeast extract, $0.05 \% \mathrm{CaCl}_{2}$ and $0.1 \% \mathrm{NaCl}$. Inoculum was incubated at $37{ }^{\circ} \mathrm{C}$ with shaking at $150 \mathrm{rpm}$ and incubation period was varied $(8,12,16,20$, and 24 hours).

Bacterial cells were separated from the medium by cold centrifugation at $10,000 \times \mathrm{g}$ for 15 minutes. Bacterial pellet was then resuspended with fresh medium. Immobilization was done by inserting paddy straw powder in the bacterial suspension $(0.1 \mathrm{~g}$ powder in $10 \mathrm{~mL}$ bacterial suspensions), incubated at $30{ }^{\circ} \mathrm{C}$ with shaking at 90 rpm for 180 minutes.

The effectiveness of immobilization was determined by measuring the dry weight of the bacteria adsorbed on the powder and the activity of the lipase produced. The weight of the adsorbed bacteria was determined by measuring the value of optical density $\left(\mathrm{OD}_{600}\right)$ of the bacterial suspensions before and after immobilization. The difference values were then calibrated on a curve of $\mathrm{OD}_{600}$ against the cell dry weight (cdw) of the bacteria.

Lipase activity was assayed using the technique proposed by Lee et $\mathrm{al}^{13}$. Substrate emulsion was prepared by mixing $10 \mathrm{mM}$ pnitrophenyl palmitate (pnpp) with buffer and ethanol at a ratio of 1:95:4 (v/v/v). The reaction was started by adding $0.01 \mathrm{~g}$ immobilized bacteria into $980 \mathrm{~mL}$ substrate emulsion, then incubated at a given temperature for 20 minutes. The activity was determined by measuring the absorbance of the catalysis product of p-nitrophenol at $405 \mathrm{~nm}$. Lipase activity is expressed in units/g which is defined as mole product (p-nitrophenol) generated by lipase per minute per gram of immobilized bacteria.

\section{Characterization of Lipase Produced by Immobilized Bacteria}

Lipase produced by immobilized bacteria was characterized by parameters of $\mathrm{pH}$, temperature, catalytic stability and stability in methanol and ethanol. Effect of $\mathrm{pH}$ on lipase activity was measured at $37^{\circ} \mathrm{C}$ using $50 \mathrm{mM}$ buffer with $\mathrm{pH}$ range of 6.0 to 10.0 . The buffer used included sodium phosphate buffer ( $\mathrm{pH} 6.0$ to 8.0 ) and glycine- $\mathrm{NaOH}$ (pH 8.5 to 10.0). Effect of temperature on lipase activity was determined by measuring 
the enzyme activity at various temperatures in the range of 30 to $60^{\circ} \mathrm{C}$.

Catalytic stability of lipase produced by immobilized bacteria was determined by measuring the residual activity of an enzyme on 10 times catalysis cycle. Stability of lipase on methanol and ethanol were determined by measuring the residual activity of an enzyme after incubated for 60 minutes in a solution of alcohol with a concentration of 0 $60 \%(\mathrm{v} / \mathrm{v})$ at $37^{\circ} \mathrm{C}$.

\section{RESULTSAND DISCUSSION}

Based on the identification result using API 20E system (Table 1), lipase-producing bacteria isolated from oil contaminated soil at the traditional market Singaraja Bali most likely belong to species of Acinetobacter baumannii. The bacteria have rod-shaped cell and include a group of gramnegative bacteria.

Some researchers report lipase production by bacteria from the genus of Acinetobacter, such as Acinetobacter baumannii BD5 ${ }^{14}$, Acinetobacter baylyi ${ }^{15}$, and Acinetobacter junii ${ }^{16}$. Bacteria of this genus can also be used in the biodegradation of organic and inorganic waste, and are able to produce biomolecules such as polysaccharides, polyesters, and biosurfactant ${ }^{17}$. Effect of Activation of Paddy Straw Powder on Immobilization of Bacteria

Activation of paddy straw powder with $20 \%\left(\mathrm{w} / \mathrm{v}\right.$ ) $\mathrm{CaCl}_{2}$ solution causes changes in the surface structure of the powder. SEM results indicate that material's surface becomes more rough after activated by $\mathrm{CaCl}_{2}$ (Figure 1.B). Meanwhile, untreated straw powder showed a smoother surface (Figure 1.A).

Activation of paddy straw powder increases the number of Acinetobacter baumannii adsorbed on the material (Figure 2). Untreated powder was able to adsorb bacteria of $0.1 \mathrm{~g} / \mathrm{g}$ adsorbent. Activation of powder using $\mathrm{CaCl}_{2}$ solution to a concentration of $12.5 \%(\mathrm{w} / \mathrm{v})$ has not been able to increase the number of bacteria adsorbed. Increment of adsorbed bacteria occurs when using paddy straw powder activated with a solution of $\mathrm{CaCl} 2$ above $12.5 \%$. Optimum immobilization is achieved using powder activated with $20 \% \mathrm{CaCl}_{2}$, giving adsorbed bacteria at the amount of $0.169 \mathrm{~g} / \mathrm{g}$ adsorbent. Increasing concentrations of $\mathrm{CaCl}_{2}$ further does not increase the adsorption of bacteria on the material.

The activity of lipase produced by immobilized bacteria (Figure 2) is generally in line with the number of bacteria adsorbed on the paddy straw powder. Increased lipase activity is seen in immobilization of bacteria using powder activated with $\mathrm{CaCl}_{2}$ concentration above $7.5 \%(\mathrm{w} / \mathrm{v})$. Interestingly, immobilization of bacteria using powder activated by $15 \% \mathrm{CaCl}_{2}$ upwards gives a dramatic increment of lipase activity. Moreover, optimal lipase activity of 0.42 units/g is reached when using straw powder activated with $20 \%$ $\mathrm{CaCl}_{2}$. However, activation of powder with $\mathrm{CaCl}_{2}$ concentrations higher than $20 \%$ does not improve lipase activity of immobilized bacteria, but tends to decrease it, instead.

Adsorption of bacteria on straw powder is influenced by the characteristics of the pores or interstices formed on the material after activated by $\mathrm{CaCl}_{2}$. Analysis of EDS (Energy Dispersive Spectroscopy) showed the presence of $\mathrm{Ca}^{2+}$ cations on the surface of the activated powder (data not shown). This ion is still trapped in the

Table 1. Result of bacterial identification using API 20E system

\begin{tabular}{ll} 
Biochemical Test Result \\
\hline
\end{tabular}

ONPG (2-nitrofenil-BD-Galaktopiranosida)

$\mathrm{ADH}$ (L-Arginin)

LDC (L- Lisin)

ODC (L- Ornitin)

CIT (Trinatrium sitrat)

$\mathrm{H}_{2} \mathrm{~S}$ (Natrium tiosulfat)

URE (Urea)

TDA (L- Triptofan)

IND (L- Triptofan/ Indole)

VP (Natrium piruvat)

GEL (Gelatin)

GLU (D- Glukosa)

MAN (D- Manitol)

INO (Inositol)

SOR (D- Sorbitol)

RHA (L- Rhamnosa)

SAC (D- Sakarosa)

MEL (D- Melibiosa)

AMY (Amigdalin)

ARA (L- Arabinosa)

Ox (Oksidase)

Katalase

Source: Laboratorium Klinik Nikki Medika, Denpasar 
(A)

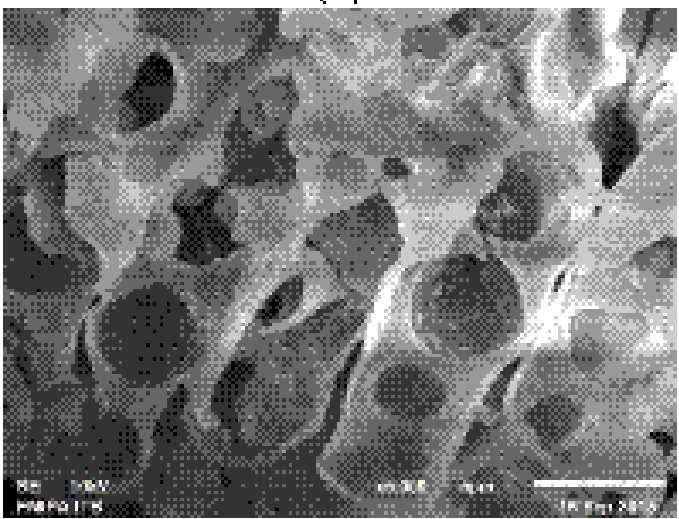

(B)

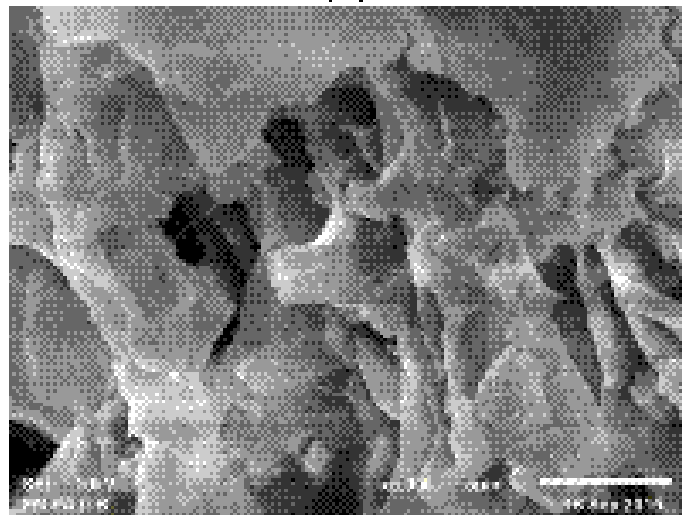

Fig. 1. Surface morphology of paddy straw powder obtained using scanning electron microscopy.

SEM was conducted on the powder without (A) and with (B) treatment of $20 \%(\mathrm{w} / \mathrm{v}) \mathrm{CaCl}_{2}$

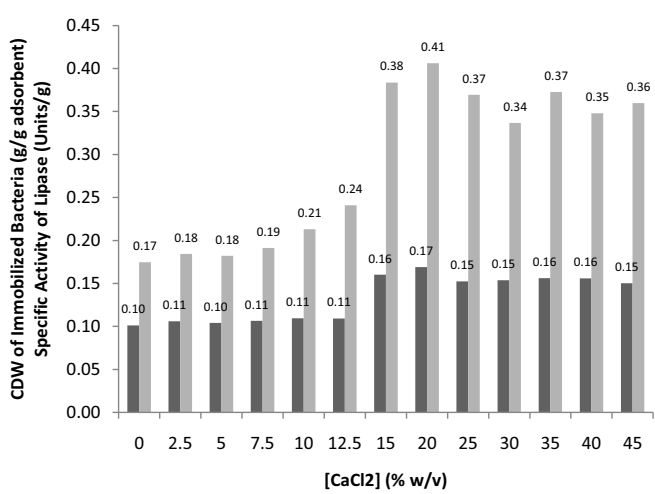

Fig. 2. Cell dry weight of adsorbed bacteria ( $\square$ ) and lipase activity of immobilized bacteria ( $\square$ ) on immobilization of bacteria using paddy straw powder activated with various concentration of $\mathrm{CaCl}_{2}$

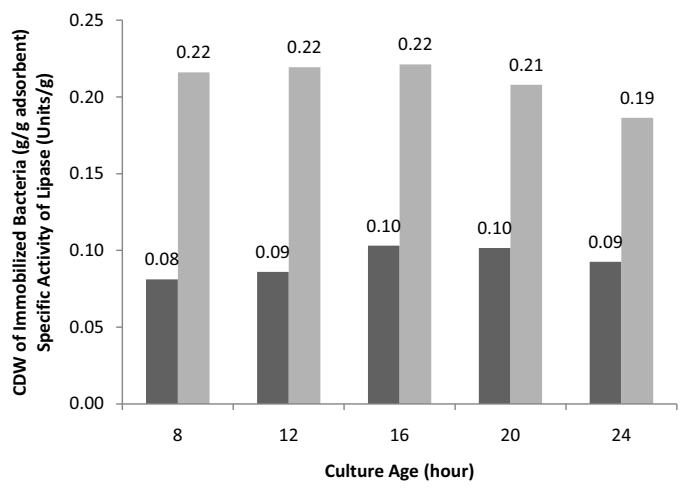

Fig. 4. Cell dry weight of adsorbed bacteria $(\square)$ and lipase activity of immobilized bacteria ( $\square$ ) on immobilization of bacteria with variation of culture age

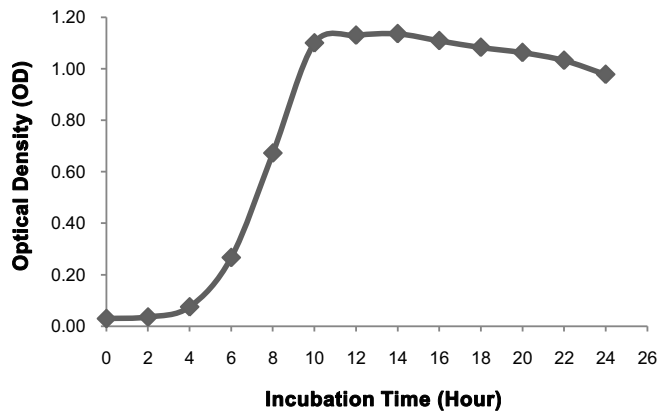

Fig. 3. Growth Curve of Acinetobacter baumannii

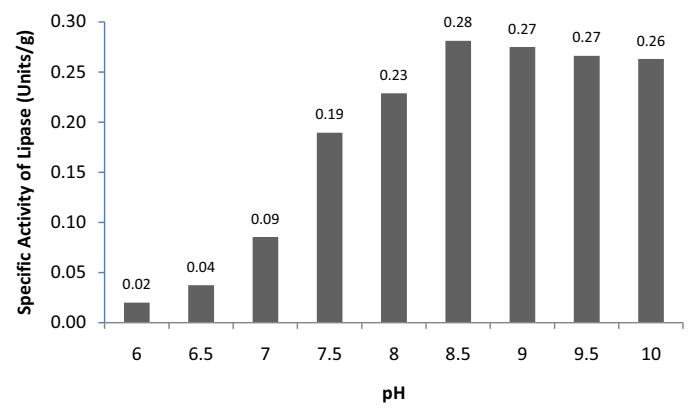

Fig. 5. Specific activity of lipase produced by immobilized bacteria at various $\mathrm{pH}$ 
material and can affect the binding of the bacteria to the material that generally occurs through hydrophobic and electrostatic interactions ${ }^{18}$.

The existence of $\mathrm{Ca}^{2+}$ on the activated paddy straw powder also increases the activity of lipase produced by immobilized bacteria. Lipase generally does not require cofactors like most other enzymes, however cation divalent such as $\mathrm{Ca}^{2+}$ is often found to increase the activity of lipase ${ }^{15,19,20,21}$.

Effect of Culture Age on Immobilization of Bacteria

The growth curve of Acinetobacter baumannii is shown in Figure 3. Bacteria begin a phase of adaptation for the early four hours. The bacteria subsequently enters the logarithmic phase characterized by an increase in bacterial growth in 6-10 hours incubation time. After that, the bacteria undergo constant growth phase up to 24 hours incubation period.

Generally, maximum extracellular lipase is produced by bacteria in the late of logarithmic phase $^{22}$. Referring to the growth profile of the bacteria, it is expected that Acinetobacter baumannii produces optimum lipase after incubated for 10 to 24 hours. Therefore, immobilization of bacteria was conducted by varying the age of the culture (incubation time) in the range of 8-24 hours, and the results are shown in Figure 4.

Figure 4 showed that culture age gives small effect on the number of bacteria adsorbed on straw powder. Improved culture age from 8 to 16 hours slightly increases the weight of the bacteria adsorbed from 0.081 into $0.103 \mathrm{~g} / \mathrm{g}$ adsorbent. The use of a culture older than 16 hours no longer increases the amount of the adsorbed bacteria, but tends to decrease them.

Immobilization of bacteria using 8-20 hour old culture showes high lipase activity with the value around 0.22 units/g (Figure 4). These results indicate an incubation period of 8 to 20 hours causing bacteria in optimal physiological conditions for producing lipase. When viewed from the growth curve of bacteria (Figure 3 ), the incubation time of 10-20 hours is the stationary phase of bacteria and lipase are produced when bacteria enters the beginning of this phase. However, the incubation time of 8 hours is still a logarithmic phase of bacteria, but the activity of lipase produced is high. These results indicate that the bacteria start producing lipase when entering the logarithmic phase.

Optimum immobilization is achieved when using 16 hours incubated culture with the acquisition of lipase activity of 0.221 units/g (Figure 4). Using a culture incubated for more than 16 hours caused decrease lipase activity and amounted to 0.186 units/g on the use of 24-hourold culture. In terms of bacterial growth curve (Figure 3), it is seen in a 24-hour incubation period, the bacteria begin to enter the death phase indicated by the decline in growth. In this phase, secondary metabolites produced by bacteria,

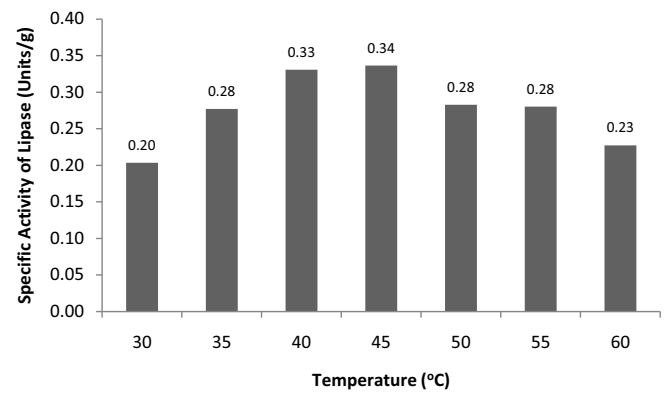

Fig. 6. Specific activity of lipase produced by immobilized bacteria at various temperature

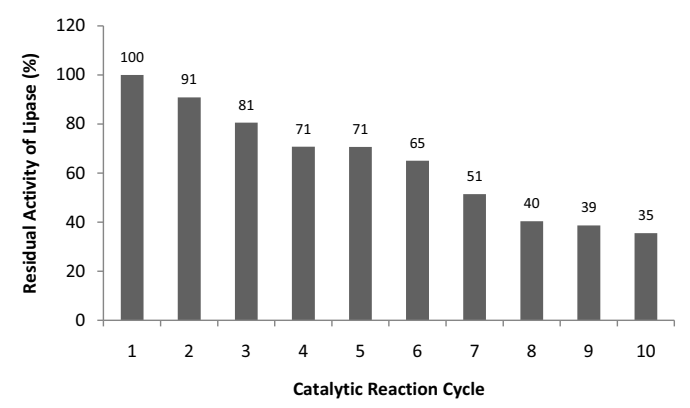

Fig. 7. Residual activity of lipase produced by immobilized bacteria for ten catalysis cycle

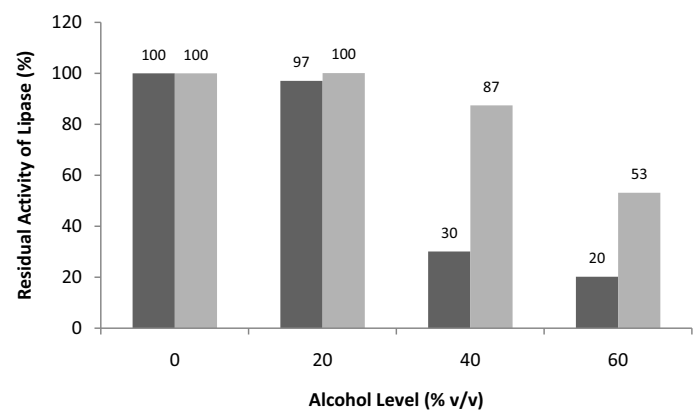

Fig. 8. Residual activity of lipase produced by immobilized bacteria after incubation in various consentration of ethanol ( $\square$ ) and methanol ( $\square)$ 
including lipase will be degraded as a source of nutrients for bacterial growth along with the reduced nutrients from the media.

\section{Effect of $\mathrm{pH}$ on the Activity of Lipase Produced by} Immobilized Bacteria

Figure 5 showed the specific activity of lipase from immobilized Acinetobacter baumannii at various $\mathrm{pH}$. Lipase produced is stable at alkaline $\mathrm{pH}$ range of 7.5 to 10 and achieves optimal value at $\mathrm{pH} 8.5$ with an specific activity of 0.28 units/g. At a neutral and acidic environment $(\mathrm{pH}<7.5)$ lipase activity of immobilized bacteria declines drastically. Based on the characters owned, lipase from Acinetobacter baumannii is very well developed for the detergent industry. As detergent additives, lipase should be stable in extreme conditions such as $\mathrm{pH} 8-11$, and a temperature of $20-50^{\circ} \mathrm{C}^{23}$.

Lipase produced by bacteria of the genus Acinetobacter are generally stable at alkaline $\mathrm{pH}$. Uttatree et al. reported lipase from Acinetobacter baylyi isolated from sea mud in Angsila, Thailand has optimal activity at $\mathrm{pH} 8.0$ and is stable in the $\mathrm{pH}$ range 6-9 ${ }^{15}$. Furthermore, lipase produced by Acenitobacter johnsonii strain LP28 showes good activity in the range $\mathrm{pH}$ 8-11 with an optimum activity at $\mathrm{pH} 9^{24}$.

Meanwhile, Park et al. cloned and expressed lipase gene of Acinetobacter baumanni BD5 in E. coli BL21. Lipase produced has optimal activity at $\mathrm{pH} 8.3$, but has a very narrow $\mathrm{pH}$ range. Lipase activity goes down drastically at $\mathrm{pH}$ above and below the optimum value ${ }^{14}$. When compared with the Acinetobacter baumanni isolated from oil contaminated soil in this study, lipase produced has a wider $\mathrm{pH}$ range (7.5 to 10 ), so it is better to use as biocatalyst.

\section{Effect of Temperature on the Activity of Lipase Produced by Immobilized Bacteria}

The specific activity of lipase from immobilized Acinetobacter baumannii at various temperatures is shown in Figure 6. Lipase produced shows good stability at wide temperature range $\left(30-60^{\circ} \mathrm{C}\right)$. The optimum lipase activity is achieved at a temperature of $45^{\circ} \mathrm{C}$ with a value of 0.34 units/ g. At temperatures above and below optimum value, lipase activity is still high. At $30^{\circ} \mathrm{C}$, lipase from immobilized bacteria still shows activity up to $60.5 \%$ of its optimum activity. Whereas at $60^{\circ} \mathrm{C}$, lipase still able to maintain its activity up to $67.5 \%$ of its optimum activity.
Lipase obtained in this study has a temperature stability similar to lipase of Acinetobacter baumannii BD5 cloned in E. coli $B L 21^{14}$. The resulting lipase shows good stability at temperatures of $20-50^{\circ} \mathrm{C}$ with an optimum activity at a temperature of $35^{\circ} \mathrm{C}$. However, lipase from Acinetobacter baumannii isolated from soil contaminated oil obtained in this study were more stable to high temperatures.

Lipase from other Acinetobacter has a narrower temperature stability range. Acinetobacter junii BK43 isolated from oil contaminated soil in South Korea produces lipase with an optimum activity at a temperature of $30{ }^{\circ} \mathrm{C}$, but the temperature stability range is very narrow ${ }^{16}$. Meanwhile, lipase from Acinetobacter baylyi isolated from the sea mud in Angsila Thailand showed optimum activity at a relatively high temperature, i.e. $60^{\circ} \mathrm{C}$. However, at temperatures outside the optimum value, lipase activity drops drastically ${ }^{15}$. Thus, lipase obtained from Acinetobacter baumannii in this study has the advantage in terms of temperature stability, so it is very potential to be developed as a biocatalyst.

\section{Catalytic Stability of Lipase Produced by Immobilized Bacteria}

Acinetobacter baumannii immobilized on paddy straw powder showed good catalytic stability. Immobilized bacteria able to maintain more than $50 \%$ of its lipase activity after seven catalysis cycle (Figure 7). Catalysis processes more than seven times cause lipase activity of immobilized bacteria dropped significantly and only remaining $35 \%$ after ten times catalysis. Based on this results, immobilized bacteria should be used no more than seven times.

Other studies on bacterial immobilization showed improved stability and hight yield of lipase produced. Chandorkar et al. has immobilized Aspergillus niger on alginate. The immobilized bacteria are able to produce lipase that can sustain its activity up to four catalysis cycle ${ }^{25}$. Meanwhile, Pseudomonas aeruginosa mutant cell immobilized on agarose able to produce lipase for seven cycle ${ }^{26}$. Advantages of this study lies in the material used for the immobilization of Acinetobacter baumanni, namely paddy straw powder is abundant and cheap, so it is economically more profitable.

Stability of Immobilized Bacteria Against Alcohol Figure 8 shows the stability of 
immobilized Acinetobacter baumannii against methanol and ethanol. Immobilized bacteria are more stable to methanol than ethanol. After incubation for one hour in $20 \%(\mathrm{v} / \mathrm{v})$ methanol, immobilized bacteria are still able to maintain $100 \%$ their lipase activity, whereas in $20 \%$ (v/v) ethanol lipase activity falls slightly to $97 \%$ of the activity without treatment with alcohol. Methanol at a concentration of $40 \%(\mathrm{v} / \mathrm{v})$ has decreased lipase activity only by $13 \%$, while in $40 \%$ (v/v) ethanol the activity drops significantly to $30 \%$ of the initial activity. The concentration of ethanol $60 \%(\mathrm{v} / \mathrm{v})$ causes dramatic decrease of lipase activity to $20 \%$, while in $60 \%(\mathrm{v} / \mathrm{v})$ methanol lipase activity remains at $53 \%$ of the initial activity.

Alcohol toxicity to the bacteria depends on the amount of solvent that can be entered into the bacterial cell membrane. This is influenced by their solubility in water and ability to carry out partition into the hydrophobic cell membrane ${ }^{27}$. Methanol is more polar than ethanol, making it more difficult to get into the cell membranes of bacteria that are non polar. This causes the bacteria to be more resistant to methanol than ethanol, so as to produce lipase more.

Because of its excellent stability against methanol, immobilized Acinetobacter baumannii obtained in this research is potential to be developed as a biocatalyst in the production of biodiesel. Biodiesel is produced through transesterification reaction of vegetable oil with alcohol (methanol or ethanol) with the aid of a catalyst, so that the necessary biocatalyst stable in the alcohol.

\section{CONCLUSION}

Acinetobacter baumannii isolated from oil-contaminated soil at the traditional market in Singaraja Bali which were immobilized on paddy straw powder capable of producing lipase. Lipase produced stable at alkaline $\mathrm{pH}$ (7.5 to 10$)$ and a temperature of $30-60{ }^{\circ} \mathrm{C}$, thus can potentially be used in the detergent industry. Immobilized Bacteria have good catalytic stability up to seven times usage. Lipase produced also have good stability in methanol, so it is very potential to be developed as a biocatalyst in the production of biodiesel.

\section{ACKNOWLEDGMENTS}

This work was fully funded by Universitas Pendidikan Ganesha.

\section{REFERENCES}

1. Eltaweel, M. A., Rahman, R. N. Z. R. A., Salleh, A. B., Basri, M. An Organic Solvent-Stable Lipase From Bacillus sp. Strain 42. Annals of Microbiology, 2005; 55(3): 187-192

2. Sharma, R., Chisti, Y., Banerjee, U. C. Production, Purification, Characterization, and Application of Lipases, Biotechnology Advances, 2001; 19: 627-662

3. Dutra, J. C. V., Terzi, S. C., Bevilaqua, J. V., Damaso, M. C. T., Couri, S., Langone, M. A. P., et al. Lipase production in solidstate fermentation monitoring biomass growth of Aspergillus niger using digital image processing. Applied Biochemistry and Biotechnology, 2008; 147: 63-75

4. Griebeler, N., Polloni, A.E., Remonatto, D., Arbter, F., Vardanega, R., Cechet, J.L., et al. Isolation and screening of lipase-producing fungi with hydrolytic activity. Food and Bioprocess Technology, 2009; 4: 578-586

5. Zeng, J., Du, W., Liu, X., Dai, L. Study on the effect of cultivation parameters and pretreatment on Rhizopus oryzae cell-catalyzed transesterification of vegetable oils for biodiesel production. Journal of Molecular Catalysis B: Enzymatic, 2006; 43: 15-18

6. Fukuda, H., Kondo, A., Tamalampudi, S. Bioenergy: sustainable fuels from biomass by yeast and fungal whole-cell biocatalysts. Biochemical Engineering Journal, 2009; 44: 212

7. Xiao, M., Mathew, S., Obbard, J.P. Biodiesel fuel production via transesterification of oils using lipase biocatalyst. GCB Bioenergy, 2009; 1: $115-125$

8. Indumathi, R., Raj, S.P. Biodiesel production from microbial whole cell biocatalyst. Journal of Biodiversity and Environmental Sciences, 2013; 3(8): 94-101

9. Cai T, Chen L, Ren Q, Cai S, Zhang J. The biodegradation pathway of triethylamine and its biodegradation by immobilized Arthrobacter protophormiae cells. J. Hazard Mater, 2011; 186:59-66

10. Liu, H., Guo, L., Liao, S., Wang, G. Reutilization of immobilized fungus Rhizopus sp. LG04 to reduce toxic chromate. Journal of Applied Microbiology, 2012; 112: 651-659 
11. Parwata, I P., Sukarta, I N. Lipase Stabil Pelarut Organik dari Bakteri Isolat Tanah Terkontaminasi Minyak di Pasar Anyar Singaraja, Bali. Prosiding Seminar Nasional Riset Inovatif I, 2013; 573-579

12. Prescott, H. (ed): Laboratory Exercises in Microbiology, 5th edition. The McGraw-Hill Companies, 2002; 93-102

13. Lee, D., Koh, Y., Kim, K., Kim, B., Choi, H., Kim, D., Suhartono, M. T., Pyun, Y. Isolation and Characterization of Thermophilic Lipase from Bacillus thermoleovorans ID-1, FEMS Microbiology Letters, 1999; 179: 393-400

14. Park, I.H., Kim, S.H., Lee, Y.S., Lee, S.C., Zhou, Y., Kim, C.M., Ahn, S.C., Choi, Y.L. Gene Cloning, Purification, and Characterization of a Cold-Adapted Lipase Produced by Acinetobacter baumannii BD5. Journal of Microbiology Biotechnology, 2009; 19(2): 128135

15. Uttatree, S., Winayanuwattikun, P., Charoenpanich, J. Isolation and Characterization of a Novel Thermophilic-Organic Solvent Stable Lipase From Acinetobacter baylyi. Applied Biochemistry Biotechnology, Published online: 24 February 2010

16. Anbu, P., Noh, M.J., Kim,, D-H., Seo, J-S., Hur, B-K., Min, K.H. Screening and optimization of extracellular lipases by Acinetobacter species isolated from oil-contaminated soil in South Korea. African Journal of Biotechnology, 2011; 10(20): 4147-4156

17. El-Haleem, D.A. Acinetobacter: Environmental and biotechnological applications. African Journal of Biotechnology, 2013; 2(4): 71-74

18. Górecka, E., Jastrzêbska, M. Immobilization techniques and biopolymer carriers. Biotechnology Food Sciences, 2011; 75: 65-86

19. Gupta, R., Gupta, N., dan Rathi, P. Bacterial Lipases: an Overview of Production, Purification, and Biochemical Properties,
Applied Microbiology Biotechnology, 2004; 64: 763-781

20. Moreno, M. L., Garcia, M. T., Ventosa, A., Mellado, E. Characterization of Salicola sp. IC10, a Lipase- and Protease-producing Extreme Halophili, FEMS Microbiology Ecology, 2009; 68: $59-71$

21. Sulong, M.R., Abdul Rahman, R.N.Z.R., Salleh, A.B., Basri, M. A Novel Organic Solvent Tolerant Lipase from Bacillus sphaericus 205y: Extracellular Expression of a Novel OST-Lipase Gen, Protein Expression and Purification, 2006; 49: 190-195

22. Jaeger, K. E., Ransac, S., Dijkstra, B. W., Colson, C., Heuvel, M. V., Misset, O. Bacterial Lipases, FEMS Microbiology Reviews, 1994; 15: 29-63

23. Kasana, R.C., Kaur, B., Yadav, S.K. Isolation and identification of a psychrotrophic Acinetobacter sp. CR9 and characterization of its alkaline lipase, Journal of Basic Microbiology, 2008; 48: 207-212

24. Wang, H.K., Shao, J., Wei, Y.J., Zhang, J., Qi, W. A Novel Low-Temperature Alkaline Lipase from Acinetobacter johnsonii LP28 Suitable for Detergent Formulation. Food Technology Biotechnology, 2011; 49(1): 96-102

25. Chandorkar, V., Gomashe, A. V., Parlewar, S. Production of lipase by Immobilized Cells of Aspergillus niger. International Journal of Current Microbiology and Applied Sciences, 2014; 3(8): 703-707

26. Bisht, D., Yadav, S.K., Darmwal, N.S. Optimization of immobilization conditions by conventional and statistical strategies for alkaline lipase production by Pseudomonas aeruginosa mutant cells: scale-up at bench-scale bioreactor level. Turkish Journal of Biology, 2013; 37: 392404

27. de Bont, J.A. Solvent-tolerant bacteria in biocatalysis.Trends Biotechnology, 1998; 16: 493-499. 